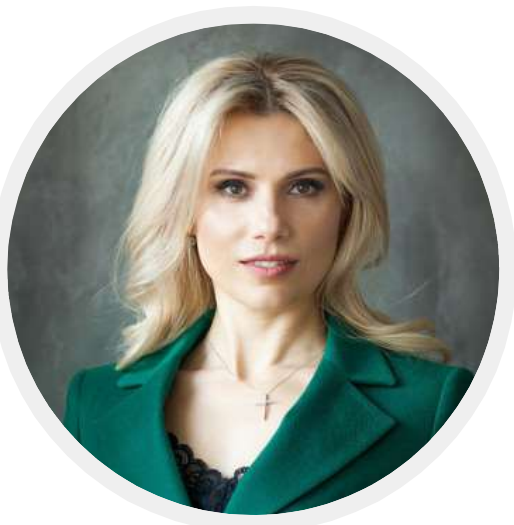

Олена Бориславська

доктор юридичних наук, доцент,

професор кафедри конституційного права Львівського національного університету імені Івана Франка

Львів, Україна

olenabor@gmail.com

ORCID https://orcid.org/0000-0001-8338-0966 ResearcherID https://publons.com/researcher/H-2177-2019/

AMICUS CURIAE 1

щодо відповідності законопроекту про внесення змін до статті 93

Конституції України (щодо законодавчої ініціативи народу)

(реєстр. № 1015) вимогам статей 157 і 158 Конституції України²

\title{
AMICUS CURIAE \\ on the issues of constitutionality (conformity with provisions 157, 158 of the Ukrainian Constitution) of the draft on amending the Constitution of Ukraine concerning the people's legislative initiative
}

\section{Olena Boryslavska}

associate professor, Ph. D. (Law), Ivan Franko National University of Lviv, Ukraine

\section{Вступ}

Діяльність Верховної Ради України IX скликання розпочалася із активної реалізації Главою держави права подавати законопроекти про внесення змін до Конституції України. Так, уже 29 серпня 2019 року було зареєстровано сім таких законопроектів, що були попередньо схвалені Верховною Радою України:

1. № 1013 від 29.08.2019 про внесення змін до Конституції України (щодо скасування адвокатської монополії);

2. №1014 від 29.08.2019 про внесення змін до статті 106 Конституції України (щодо закріплення повноважень Президента України утворювати незалежні регуляторні органи, Національне антикорупційне бюро України, призначати на посади та звільняти з посад Директора Національного антикорупційного бюро України і Директора Державного бюро розслідувань);

\footnotetext{
1 Бориславська О.М., доктор юридичних наук, доцент, професор кафедри конституційного права Львівського національного університету імені Івана Франка, член Науково-консультативної ради при Конституційному Суді України 2 Подається в авторській редакції: Джерело: Матеріали справи № 2-250/2019 (5582/19) до Висновку КСУ № 5 -в/2019. URL: http://www.ccu.gov.ua/docs/2909
} 
3. №1015 від 29.08.2019 про внесення змін до статті 93 Конституції України (щодо законодавчої ініціативи народу);

4. №1016 від 29.08.2019 про внесення змін до статей 85 та 101 Конституції України (щодо уповноважених Верховної Ради України);

5. №1017 від 29.08.2019 про внесення змін до статей 76 та 77 Конституції України (щодо зменшення конституційного складу Верховної Ради України та закріплення пропорційної виборчої системи);

6. №1027 від 29.08.2019 про внесення змін до статті 81 Конституції України (щодо додаткових підстав дострокового припинення повноважень народного депутата України);

7. №1028 від 29.08.2019 про внесення зміни до статті 85 Конституції України (щодо консультативних, дорадчих та інших допоміжних органів Верховної Ради України).

Крім того, серед перших прийнятих законів Верховна Рада України IX скликання ухвалила i закон № 7203 про внесення змін до Конституції України про внесення змін до статті 80 Конституції України (щодо недоторканності народних депутатів України).

Частина із цих законопроектів передбачають взаємопов'язані за змістом зміни та стосуються взаємозалежних елементів конституційної системи, що, у разі їх прийняття, можуть суттєво вплинути не тільки на систему поділу влади, але й на конституційну систему України загалом, та в результаті призвести до обмеження прав і свобод людини і громадянина (забороненого ст. 157 Конституції України).

Це, передусім, стосується законопроектів №1014 (щодо закріплення повноважень Президента України утворювати незалежні регуляторні органи, Національне антикорупційне бюро України, призначати на посади та звільняти з посад Директора Національного антикорупційного бюро України і Директора Державного бюро розслідувань), №1015 (щодо законодавчої ініціативи народу), №1017 (щодо зменшення конституційного складу Верховної Ради України та закріплення пропорційної виборчої системи) та №1027 (щодо додаткових підстав дострокового припинення повноважень народного депутата України). Відтак, вбачаємо за необхідне наголосити, що предметом аналізу на предмет відповідності статтям 157 та 158 Конституції України має бути не тільки кожен із поданих законопроектів зокрема, але й всі вони у системній єдності.

\section{I. Методологічні підходи до здійснюваного Конституційним Судом України конститу- ційного контролю за законопроектами про внесення змін до Конституції України}

\section{1. Мета, обсяг та методологія конституційного контролю}

Важливим питанням, яке постає у ході надання висновків про відповідність законопроектів про внесення змін до Конституції України вимогам статей 157 та 158, є мета та обсяг здійснюваного конституційного контролю, особливо в аспекті контролю за змістом пропонованих змін. Найбільш поширеними є два підходи, кожен із яких більше схильний до застосування тієї чи іншої методології здійснення конституційного контролю.

Перший - вузький - підхід передбачає, що Конституційний Суд має аналізувати законопроекти лише на предмет наявності в тексті пропонованих змін положень, які безпосередньо передбачають скасування чи обмеження прав і свобод людини і громадянина або спрямовані на ліквідацію незалежності чи порушення територіальної цілісності України. Тобто охоронюваними Конституційним Судом об’єктами є лише прямо згадані в ч. 1 ст. 157 «права і свободи людини і громадянина», «незалежність України» та «територіальна цілісність України». Це, як видається, спонукає до застосування формального підходу в оцінці змісту законопроектів та часто зводиться до констатації факту, що «законопроект не передбачає скасування чи обмеження прав людини, не спрямований на ліквідацію незалежності чи порушення територіальної цілісності»; що вважається достатньою підставою для висновку про змістовну відповідність законопроекту вимогам статті 157. Застосуванню згаданого підходу сприяє поширений протягом тривалого часу нормативізм, який глибоко вкорінився в правосвідомість та націлює на формальний аналіз конституційності виключно у рамках сформульованої конституційної норми. 
Другий - широкий - підхід передбачає, що коло охоронюваних об'єктів, окрім безпосередньо згаданих в ч. 1 ст. 157, охоплює також безпосередньо пов'язані з ними цінності та інструменти конституційної демократії, без яких гарантування прав та свобод людини і громадянина $є$ неможливим. Такими, зокрема, є людська гідність, демократія, верховенство права, поділ влади. Згадані цінності перебувають у системній єдності та складають основу будь-якої конституційної демократії, а зазіхання на конституційному рівні на одну із них може призвести до демонтажу системи конституційної демократії, яка і є реальною гарантією прав людини.

Широкий підхід спонукає до застосування складнішого інструментарію оцінки законопроектів, що більшою мірою відповідає потребам реалізації верховенства права. Він передбачає не формальну перевірку законопроекту на предмет наявності чи відсутності в ньому положень, які прямо «передбачають скасування чи обмеження прав людини, спрямовані на ліквідацію незалежності чи порушення територіальної цілісності України», а глибокий та системний аналіз пропонованих змін на предмет того, чи не становлять вони загрози конституційній демократії та таких її інститутів, як поділ влади та верховенство права.

Видається, що потребам сучасної конституційної держави більшою мірою відповідає саме другий - широкий - підхід, відповідно до якого метою конституційного контролю за законопроектами про внесення змін до конституції є охорона як безпосередньо згаданих у частині 1 статті 157 об'єктів - прав і свобод людини і громадянина, незалежності та територіальної цілісності Украӥни, так і відображених у Конституції України цінностей конституційної демократії, які у сукупності становлять безумовну гарантію недоторканності згаданих об'єктів.

Досягнення цієї мети вбачається за можливе лише за умови застосування відповідної методології здійснення конституційного контролю. В основі цієї методології не можуть перебувати виключно нормативізм та формальний підхід, що передбачає поверхневий аналіз оцінюваного тексту на предмет його відповідності конституційним заборонам. Натомість, варто застосовувати складніший, проте більш адекватний цій меті, інструментарій, який більшою мірою відповідає потребам реалізації верховенства права та проводити глибокий аналіз пропонованих змін на предмет того, чи не становлять вони загрози конституційній демократії.

\section{2. Необхідність застосування системного підходу}

Як уже зазначалося вище, на розгляді в Конституційному Суді України перебуває відразу декілька законопроектів про внесення змін до Конституції України, частина із яких передбачають взаємопов'язані за змістом зміни, зокрема стосуються механізму поділу влади та інших елементів конституційної системи (зокрема народного законодавчого вето, що є формою безпосередньої демократії), що, у разі їх прийняття, можуть суттєво вплинути на конституційну систему України.

Логіка та мотиви суб'єкта подання законопроектів про внесення змін до Конституції України, на жаль, не оголошена публічно, а відтак незрозуміло, яка мета переслідується таким «роздрібненим» способом проведення конституційної реформи, коли пропоновані конституційні зміни в один день реєструються у вигляді кількох самостійних законопроектів. Однак, місія та завдання Конституційного Суду України, а також мета здійснюваного ним контролю за внесенням змін до Конституції України потребують застосування системного підходу в аналізі згаданих законопроектів.

В той час як кожен законопроект зокрема може і не містити заборонених ч. 1 ст. 157 Конституції положень, однак у сукупності передбачені кількома законопроектами зміни можуть потенційно становити загрозу як безпосередньо згаданим у частині 1 статті 157 об'єктам, так і іншим інститутам конституційної демократії.

3 процедурної точки зору застосування системного підходу не обов'язково передбачає об'єднання конституційних проваджень в одне, проте вимагає формування цілісного бачення змісту пропонованих змін, оцінки потенційних ризиків та загроз охоронюваним Конституцією об’єктам, що випливають із усіх розглядуваних законопроектів про внесення змін до Конституції України в сукупності, та її відображення у висновку(ах) Конституційного Суду України.

II. Аналіз змісту законопроекту

ЧАСОПИС 2/2019| 83 


\section{1. Природа народної законодавчої ініціативи}

Виникнення інституту народної законодавчої ініціативи пов'язане із формуванням конституційних систем правління федеративних держав (США, Швейцарії), де цей інститут запроваджувався як засіб недопущення надмірної концентрації влади Федерацією та впливу на неї суб'єктів федерації3. Згодом інститут народної законодавчої ініціативи, що має кілька різновидів (власне законодавча ініціатива, конституційна ініціатива та референдна ініціатива) було поширено і на деякі унітарні держави.

Цікаво, що інститут народної законодавчої ініціативи, який на момент його виникнення запроваджувався як демократичний механізм недопущення свавілля федерації, згодом був введений і в деяких авторитарних державах. На досвід останніх досить часто посилаються українські дослідники, порівнюючи підстави, порядок внесення, процедурні аспекти подання і т. ін., що видається некоректним. Адже порівнювати однакові чи схожі інститути в конституційних та неконституційних державах можна лише з урахуванням змісту правління цих держав (конституційно обмеженого чи авторитарного). Так, в конституційних державах народна законодавча ініціатива $є$ невід'ємним елементом конституційної системи, який разом з іншими елементами забезпечує її збалансованість, несвавільність та конституційну обмеженість. Натомість в державах неконституційних вона виконує зовсім інші, часто протилежні, функції. Тож практику застосування інституту народної законодавчої ініціативи в авторитарних чи тоталітарних державах є сенс розглядати тільки з точки зору аналізу маніпулятивних можливостей цього інституту.

Аналізуючи зміст інституту народної законодавчої ініціативи, як видається, варто брати до уваги два важливі моменти.

По-перше, природу народної законодавчої ініціативи, якою є безпосередня демократія. У сучасній доктрині конституційного права народна законодавча ініціатива розглядається як одна із форм прямого народовладдя, що застосовується у деяких країнах поряд із виборами, референдумами, народним вето та іншими формами безпосередньої демократії4.

Варто наголосити на тому, що природа народної законодавчої ініціативи як форми прямого народовладдя має важливе практичне значення для України, адже наша Конституція, на відміну від низки інших (де народна законодавча ініціатива включена до розділів, присвячених законодавчій владі), містить окремий розділ, присвячений прямому народовладдю - розділ III «Вибори. Референдуми». Цей розділ перебуває під особливою конституційною охороною, оскільки внесення змін до нього передбачає ускладнену, порівняно з іншими розділами Конституції України, процедуру. Відтак, нелогічним та сумнівним з точки зору конституційності $\epsilon$ введення інституту народної законодавчої ініціативи до розділу «Верховна Рада України», присвяченому представницькій, а не безпосередній демократії.

По-друге, запроваджуючи народну законодавчу ініціативу в національну правову систему, потрібно розуміти, що вона є одним із важливих елементів конституційної системи, що будується та функціонує за певними правилами. В умовах конституційної демократії така система має відповідати параметрам внутрішньої збалансованості та обмеженості конституцією. В той же час, запровадження нових елементів до конституційної системи безумовно спричиняє такі зміни, які потребують відповідних кроків щодо її збалансування, адже попередньо існуюча рівновага неминуче порушується.

Так, інститут народної законодавчої ініціативи (за умови його реальності) $є$ вагомим важелем впливу на парламент (законодавчу владу), що, враховуючи адміністративний ресурс, яким

\footnotetext{
3 Народна законодавча ініціатива вперше з'явилася у Швейцарському кантоні Вауд у 1846 році, цього ж року у кантоні Берн було запроваджено народне вето (не референдум, як часто помилково вказується в літературі, який з'явився трохи пізніше). При частковій ревізії Конституції у 1891 році було введено «право на ініціативу» - те, що сьогодні назагал вважається законодавчою ініціативою, а тоді являло собою підписану певною кількістю громадян петицію щодо розгляду парламентом питання про прийняття чи скасування закону.

4 До прикладу: Comments on Legislative Initiative in Europe by Ms. Angelika Nussberger (Substitute Member, Germany). European Commission for Democracy Through Law (Venice Commission). CDL (2008)102*. Study no. 446 / 2007. Strasbourg, 30 September 2008. p. 23. URL: https://www.venice.coe.int/webforms/documents/default.aspx?pdffile=CDL(2008)102-e
} 
володіє виконавча влада, може сприяти ї̈ неспіврозмірному посиленню. Враховуючи той факт, що існуюча в Україні система змішаного правління допускає фактичне керівництво виконавчою владою президентом (за умови наявності президентської більшості у парламенті, що спостерігаємо сьогодні), такий крок є серйозним ударом по рівновазі в системі поділу державної влади та конституційної системи загалом.

2.2. Аналіз змісту законопроекту у системному зв'язку з іншими поданими до Верховної Ради України законопроектами про внесення змін до Конституції України

Законопроект №1015 «Про внесення змін до статті 93 Конституції України (щодо законодавчої ініціативи народу)» передбачає зміни до статті 93 Конституції України та пропонує викласти її в такій редакції:

«Право законодавчої ініціативи у Верховній Раді України належить народу, Президентові України, Кабінету Міністрів України, народним депутатам України та реалізується ними у випадках і порядку, визначених Конституцією України і законами України.

Законопроекти, визначені Президентом України як невідкладні, розглядаються Верховною Радою України позачергово.

Закон приймається відповідно до вимог законодавчої процедури, визначеної Конституцією України та законами України».

Аналізований законопроект передбачає відразу декілька важливих змін, зміст яких полягає в наступному.

По-перше, пропонується доповнити перелік суб'єктів права законодавчої ініціативи та включити до нього, окрім передбачених чинною Конституцією Президента України, Кабінету міністрів України та народних депутатів України, також «народ».

По-друге, запроваджується можливість обмеження реалізації права законодавчої ініціативи усіма згаданими суб”єктами, оскільки воно “реалізується ними у випадках і порядку, визначених Конституцією України і законами України».

По-третє, встановлюється нова норма, за якою «Закон приймається відповідно до вимог законодавчої процедури, визначеної Конституцією України та законами України».

3 приводу змісту цих норм слід наголосити на такому.

1) Стосовно розширення переліку суб'єктів права законодавчої ініціативи.

Як уже зазначалося вище, надання народові права вносити на розгляд парламенту законопроекти загалом $є$ позитивним явищем, однак така народна законодавча ініціатива $є$ формою прямого народовладдя, що є предметом регулювання Розділу III Конституції України.

Варто також враховувати, що запровадження інституту народної законодавчої ініціативи відбувається одночасно із зменшенням кількості народних депутатів України (законопроект № 1017), розширенням переліку підстав дострокового припинення повноважень народних депутатів (законопроект № 1027), розширенням повноважень Президента України (законопроект № 1014) та вже після скасування конституційного інституту депутатської недоторканності (Закон України № 7203). Системний аналіз положень наведених законопроектів та Закону України № 7203 свідчать про серйозні зміни конституційної системи України, що спрямовані на суттєве послаблення ролі парламенту та одночасне посилення ролі Президента України.

До цього слід додати, що інститути прямого народовладдя, у тому числі народної законодавчої ініціативи, потенційно пов'язані із широкими можливостями застосування маніпулятивних технологій. У конституційних державах із високим чи хоча б достатнім рівнем верховенства права і демократії ${ }^{5}$ такі ризики зведені до мінімуму. Натомість в державах неконституційних та

\footnotetext{
5 The Economist Intelligence Unit, 'Democracy Index 2018: Me too? Political participation, protest and democracy' (A report by The Economist Intelligence Unit). URL: http://www.eiu.com/Handlers/WhitepaperHandler.ashx?fi=Democracy_Index_2018.pdf\&mode=wp\&campaignid=Democracy2018;

The World Justice Project, 'WJP Rule of Law Index 2019. URL: https://worldjusticeproject.org/sites/default/files/documents/WJP-ROLI-2019Single\%20Page\%20View-Reduced_0.pdf>
} 
перехідних такі ризики є досить високими. У Індексі Демократії 2018 р.6 Україна віднесена до держав із гібридним режимом. Це, зокрема, означає, що система поділу державної влади є слабкою, а збалансованість конституційної системи є хиткою. Виходячи із цього та враховуючи зміст пропонованих змін у їх системній єдності, можна зробити висновок, що вони становлять загрозу конституційній демократії, яка формується, передусім такому її елементу як поділ влади.

2) Щодо запровадження обмеження в реалізації права законодавчої ініціативи в результаті доповнення ч. 1 ст. 93 положенням, за яким право законодавчої ініціативи «реалізується ними [суб'єктами] у випадках і порядку, визначених Конституцією України і законами України».

Чинна редакція статті 93 Конституції України передбачає лише перелік суб’єктів права законодавчої ініціативи, залишаючи відкритим питання про можливість його реалізації на розсуд самих суб'єктів. Порядок реалізації права законодавчої ініціативи визначається Конституцією України та законами, передусім - Регламентом Верховної Ради України, що є логічним та очевидним, а тому додаткової регламентації в нормі статті 93 Конституції України не потребує.

В той же час, положення «реалізується ними у випадках і порядку, визначених Конституцією і законами України», яким пропонується доповнити ч. 1 ст. 93, передбачає обмеження можливостей реалізації права законодавчої ініціативи не тільки Конституцією, але й законами.

Права суб'єктів права законодавчої ініціативи не є правами людини в розумінні статті 157 Конституції України, однак через діяльність представницьких органів, яким є Президент України, та народних представників, якими є народні депутати України, реалізується право громадян брати участь в управлінні державними справами. Відтак, встановлення обмежень на реалізацію згаданими суб'єктами права законодавчої ініціативи може призвести до обмеження конституційного права громадян, відображеного у статті 38 Конституції України.

3) Стосовно доповнення статті 93 положенням «Закон приймається відповідно до вимог законодавчої процедури, визначеної Конституцією України та законами України».

Наведене положення не $є$ таким, що може безпосередньо призвести до обмеження прав та свобод людини громадянина, проте слід наголосити на тому, що воно може внести певну невизначеність у трактування конституційних категорій «конституційна процедура» та «законодавча процедура».

Як Конституція України, так і Конституційний Суд України розрізняють конституційну та законодавчу процедури ухвалення законів. Зокрема, порушення законодавчої та водночас дотримання конституційної процедури неодноразово було підставою для відмови у відкритті Конституційним Судом України конституційного провадження щодо визнання правового акту неконституційними. Формулювання ж «відповідно до вимог законодавчої процедури, визначеної Конституцією України та законами України» фактично ототожнює два види процедури, називаючи їх законодавчою процедурою, яка може бути визначена або Конституцією, або законами України.

\section{3. Аналіз законопроекту на предмет відповідності вимогам ч. 2 ст. 157 та ст. 158 Конституції України}

Щодо внесення змін до Конституції України в умовах воєнного та надзвичайного стану сьогодні існує дві позиції, які представлені Конституційним Судом України як органом конституційного правосуддя (перевіряє факт формального запровадження воєнного чи надзвичайного стану7), та окремими суддями Конституційного Суду України (розрізняють правові режими воєнного та надзвичайного стану і умови воєнного чи надзвичайного стану8).

\footnotetext{
6 The Economist Intelligence Unit, 'Democracy Index 2018: Me too? Political participation, protest and democracy' (A report by The Economist Intelligence Unit). URL: http://www.eiu.com/Handlers/WhitepaperHandler.ashx?fi=Democracy_Index_2018.pdf\&mode=wp\&campaignid=Democracy2018

7 Зокрема, висновки КСУ №1-в/2015, №2-в/2015; 1-в/2016; 2-в/2016 та ін.

8 Окрема думка судді Мельника М.I. у справі щодо висновку КСУ №1-в/2015; Окрема думка судді Шишкіна В.I. у справі щодо висновку КСУ №1-в/2015; Окрема думка судді Сліденка І.Д. у справі щодо висновку КСУ №2-в/2015 та низка інших.
} 
Поділяючи позицію прихильників змістовного, а не формального підходу до вирішення цього питання, вважаю, однак, що фактичні «умови воєнного стану» та стан війни не повинні ставати перешкодою для необхідного, але виваженого, системного та продуманого реформування суспільних відносин, що може потребувати внесення змін до Конституції.

При цьому, видається, що до уваги слід брати не тільки наявність самої заборони вносити зміни до Конституції в умовах воєнного чи надзвичайного стану, але й причини існування таких заборон. Такими, як видається, є унеможливлення зміни Конституції під впливом чи тиском агресора чи потенційного або реального узурпатора (як індивідуального, так і колективного). Відтак, у кожному випадку розгляду Конституційним Судом України законопроекту про внесення змін до Конституції України в умовах фактичного стану війни, його підхід до аналізу таких законопроектів має бути значно більш прискіпливим, ніж в мирний час. Саме такий глибокий змістовий, а не формальний поверхневий аналіз має убезпечити від настання негативних наслідків, уникнення яких має на меті положення ч. 2 ст. 157.

Аналіз розглядуваного законопроекту на предмет відповідності ст. 158 Конституції України дає підстави зробити висновок, що він відповідає вимогам згаданої конституційної норми.

III. Висновок щодо відповідності положень законопроекту про внесення змін до Конституції України щодо народної законодавчої ініціативи вимогам статей 157, 158 Конституції України

Враховуючи викладене вище, пропонуються такі висновки щодо відповідності законопроекту вимогам статей 157, 158 Конституції України:

3.1. Положення «реалізується ними у випадках і порядку, визначених Конституцією і законами України», яким пропонується доповнити ч. 1 ст. 93 Конституції України, передбачає обмеження можливостей реалізації права законодавчої ініціативи не тільки Конституцією, але й законами. У зв’язку із тим, що через діяльність представницьких органів, яким $є$ Президент України, та народних представників, якими є народні депутати України, реалізується право громадян брати участь в управлінні державними справами (ст. 38 Конституції України), встановлення обмежень на реалізацію передбаченими суб'єктами права законодавчої ініціативи може призвести до обмеження цього конституційного права громадян.

3.2. З Застосування широкого підходу до розуміння мети і обсягу здійснюваного Конституційним Судом конституційного контролю за законопроектами про внесення змін до Конституції України (п. 1.1. цього висновку), а також проведення системного аналізу законопроекту №1015 у взаємозв’язку з іншими законопроектами про внесення змін до Конституції України (п. 1.2. цього висновку) та прийнятим Законом № 7203 дає підстави для висновку, що інші запропоновані законопроектом №1015 зміни, хоча і не передбачають прямо скасування чи обмеження прав і свобод людини і громадянина, проте становлять серйозну загрозу конституційній демократії та таким ії інститутам, як поділ влади та верховенство права, а відтак є неконституційними.

3.3. Розширення форм прямого народовладдя в конституційній державі - загалом позитивне явище, однак запровадження інституту народної законодавчої ініціативи повинно мати легітимну мету - надання громадянам додаткових можливостей впливу на прийняття рішень державою. Системний аналіз пропонованих законопроектами про внесення до Конституції змін дає підстави для висновку про те, що у своїй сукупності вони спрямовані на послаблення ролі парламенту у системі поділу влади, посилення ролі Президента. Запровадження таких змін може призвести до серйозного дисбалансу у конституційній системі, створити передумови для надмірної концентрації влади главою держави та стати загрозою конституційній демократії.

3.4. Народна законодавча ініціатива $є$ формою прямого народовладдя, що є предметом регулювання розділу III Конституції України. Враховуючи те, що розділ III передбачає особливу процедуру внесення змін із застосуванням всеукраїнського референдуму для їх затвердження, внесення положень про форми безпосередньої демократії, у тому числі про народну законодавчу ініціативу, в інші розділи є порушенням встановленої конституційної процедури. 